\title{
Chromosomal Control of Non-gliadin Proteins from the 70\% Ethanol Extract of Wheat Endosperm
}

C. Aragoncillo, M. A. Rodriguez loperena, Pilar Carbonero and F. Garcia-Olmedo

Department of Biochenistry, Universidad l'olitécnica de Madrid, E.T.S. Ingenieros Agromomus, Madrid (Spain) 
Summary. The non-gliadin fraction of the $70 \%$ ethanol extracts of compensated nulli-tetrasonics and ditelosomics of Triticum aestitum cv. Chinese Spring has been analyzed by combined electrofocusing and electrophoresis. Seventeen of the 21 protein map components of the euploid have been ascribed to eight chromosomes: $4 \mathrm{~A} \beta, 3 \mathrm{BS}, 6 \mathrm{BS}, 7 \mathrm{BS}, 3 \mathrm{D} \beta$, 4D, 5D and 7DS.

The relationship of the different map components with other proteins previously associated with the same chromosomes is discussed.

\section{Introduction}

The central role played by wheat kernel protein in the nutrition of mankind justifies the vast amount of research carried out on many aspects of its production and utilization.

Although the study of the genetic control of this protein has long been of great interest to plant breeders, significant advances in this field have taken place only recently. These have been made possible by the development of methods of ever increasing resolution for the analytical fractionation of proteins.

In particular, research on the chromosomal location of genes coding for kernel proteins has received great impetus with the production of different kinds of aneuploids, especially the ditelosomics and the compensated nulli-tetrasomics of Triticum aestivum cv. Chinese Spring developed by Sears $(1954,1966)$.

Some of the studies have dealt with chromosomal effects on total kernel protein (Eastin et al., 1967; Riley and Ewart, 1970; Jha et al., 1971; Siddiqui, 1972; Morris et al., 1973) but most have focused on specific protein fractions.

The gliadins are the group that has been more extensively investigated, both because of their possible technological significance, as a major fraction of gluten, and because of their impact on the nutritional value of wheat, as the fraction with the lowest lysine content. In earlier work (Boyd and Lee, 1967; Solari and Favret, 1967 and 1970; Shepherd, 1968; Boyd et al., 1969), chromosome assignments were based on the one-dimensional electrophoretic patterns of gliadins, but in some cases the products of genes from different chromosomes were superimposed on the electrophoretic pattern and the genes could not be unequivocally located. This problem was recently resolved by Wrigley and Shepherd (1973) using combined electrofocusing and electrophoresis. Thus, it was confirmed that genes coding for gliadins are located in homoeologous chromosome groups 1 and 6.

Glutenin, probably the fraction of greater technological importance, has been less investigated because of analytical problems. The first chromosome-glutenin component associations have been reported only recently by Orth and Bushuk (1974).

Chromosomal location of components of other protein fractions has also been investigated. Components of chloroform-methanol extract have been associated with chromosomes $7 \mathrm{D}$ and $7 \mathrm{~B}$ (GarcíaOlmedo and Carbonero, 1970). Bozzini et al. (1971) assigned two albumins to chromosomes $3 \mathrm{D}$ and $4 \mathrm{D}$ respectively and Noda and Tsunewaki (1972) have located genes for buffer soluble proteins in homoeolog. ous chromosome group 3 by electrofocusing. We have recently reported the location of purothionin genes in group 1 (García-Olmedo et al. 1974).

Proteins extracted with $70 \%$ ethanol from wheat endosperm are mostly gliadins, which are in the $40,000-80,000$ molecular weight (MW) range, but also include some glutenins, which are of higher molecular weight, and a significant amount of proteins under $40,000 \mathrm{MW}$, which migrate ahead of gliadins in electrophoresis at $\mathrm{pH} 3.2$ and have been often considered as contaminant albumins and globulins. The importance of the latter fraction is twofold: they are of great phylogenetic and taxonomic significance, as shown by the work of Johnson and coworkers (Johnson and Hall, 1965, Hall et al., 1966; Waines, 1969; Johnson, 1972), and they are richer in lysine than gluten. An attempt has been made by Waines (1973) to locate genes for components of this fraction by one-dimensional electrophoresis. Although some bands disappeared when particular chromosomes were absent, others could not be properly assigned because of lack of resolution. We 
have recently mapped this fraction by combined electrofocusing and electrophoresis and have shown that it is constituted of components extractable with chloroform-methanol but not with water and components extractable with water but not with chloroform-methanol (Rodriguez-Loperena et al., submitted). We report here the unequivocal chromosomal location of genes for the majority of the map components.

\section{Materials and Methods}

The compensated nulli-tetrasomics and the ditelosomics of Triticum aestivum cv. Chinese Spring used in this study, which are mentioned in Results, were kindly given by E. R. Sears (Columbia, Missouri, USA), T. Mello-Sampayo (Oeiras, Portugal) and J. R. Lacadena (Madrid, Spain).

Kernels and half-kernels were extracted with $70 \%$ ethanol $(10+10+10 \mathrm{v} / \mathrm{w})$, the combined extracts evaporated in vacuo, redissolved in $9 M$ urea and incorporated into the electrofocusing polymerization mixture.

Protein maps of the extracts were obtained by combined electrofocusing and electrophoresis following a method based on that of Wrigley (1970), which has been described elsewhere (Rodriguez-Loperena $e t$ al., submitted). Electrofocusing ( $\mathrm{pH}$ range 5-8) was carried out in $2 \times 140 \mathrm{~mm}$ polyacrylamide gel columns in all cases and electrophoresis (pH 3.2) in the second dimension was performed in $1 \mathrm{~mm}$ thin starch gels for wheat samples weighing less than $25 \mathrm{mg}$ and in $2 \mathrm{~mm}$ starch gels for bigger samples, usually 35-50 mg to detect minor components.

\section{Results}

The complete non-gliadin protein map of the $70 \%$ ethanol extract of Triticum aestivum cv. Chinese Spring kernels is shown in Fig. 1. Also included are partial maps of one ditelosomic and 7 nulli-tetrasomic lines with different spots missing, which account for 17 out of the 21 components of the euploid map.

Table 1 summarizes the results obtained with all the available nulli-tetrasomics and ditelosomics of homoeologous groups $3,4,6$ and 7 .

Component 1 was absent in nulli $5 \mathrm{D}$ tetra $5 \mathrm{~A}$ and nulli $5 \mathrm{D}$ tetra $5 \mathrm{~B}$, enhanced in nulli $5 \mathrm{~B}$ tetra $5 \mathrm{D}$, and normal in nulli $5 \mathrm{~A}$ tetra $5 \mathrm{D}$, nulli $5 \mathrm{~B}$ tetra $5 \mathrm{~A}$ and nulli $5 \mathrm{~A}$ tetra $5 \mathrm{~B}$. Component 21 was enhanced in nulli $1 \mathrm{~B}$ tetra $1 \mathrm{~A}$ and normal in all other nullitetrasomics of group 1. The available nullitetrasomics of group 2 (nulli $2 B$ tetra $2 A$, nulli $2 B$ tetra $2 D$, nulli $2 \mathrm{D}$ tetra $2 \mathrm{~A}$ and nulli $2 \mathrm{D}$ tetra $2 \mathrm{~B}$ ) showed the euploid phenotype.

It should be mentioned that component 9 can interfere with the observation of component 10 in some gels. For this reason, the results for homoeologous group 6 were confirmed by mapping water extracts, which we have previously shown to include component 10 but not component 9 .

Although components 12 and 13 have been listed as absent in ditelo $4 \mathrm{~A} \propto$ (Table 1), faint spots can be observed in their position which probably correspond to components contributed by the $\mathrm{D}$ genome, because
Table 1. Deviations with respect to euploid Chinese Spring of protein maps of nulli-tetrasomics and ditelosomics of homoeologous chromosome groups $3,4,6$ and 7

\begin{tabular}{|c|c|c|c|c|c|}
\hline \multirow{2}{*}{ Samples* } & \multicolumn{5}{|c|}{ Components number** } \\
\hline & 5 & 6 & 7 & 14 & 15 \\
\hline $\begin{array}{l}n 3 A \text { t } 3 B \\
n 3 A \text { t3D } \\
\text { n3B t3A } \\
\text { n3B t3D } \\
\text { n3D t3A } \\
\text { n3D t3B } \\
\text { dt } 3 B-L \\
\text { dt } 3 D-\alpha\end{array}$ & $\begin{array}{r}+ \\
++ \\
+ \\
++ \\
+ \\
- \\
+ \\
-\end{array}$ & $\begin{array}{r}t+ \\
+ \\
- \\
+ \\
+\frac{+}{t} \\
+\end{array}$ & $\begin{array}{r}++ \\
+ \\
- \\
+ \\
+\frac{1}{4} \\
+\end{array}$ & $\begin{array}{r}++ \\
+ \\
\frac{+}{5} \\
+\frac{+}{+} \\
+\end{array}$ & $\begin{array}{r}++ \\
+ \\
- \\
+ \\
+ \\
+ \\
+\end{array}$ \\
\hline \multirow{2}{*}{ Samples } & \multicolumn{5}{|c|}{ Components number } \\
\hline & 12 & 13 & 16 & 17 & \\
\hline $\begin{array}{l}\text { n4B t4A } \\
\text { n B t4D } \\
\text { n4D t4A } \\
\text { n4D t4B } \\
\text { dt } 4 . A-\alpha\end{array}$ & $\begin{array}{r}++ \\
+ \\
++ \\
+ \\
-\end{array}$ & $\begin{array}{r}+t \\
+ \\
++ \\
+ \\
-\end{array}$ & $\begin{array}{r}++ \\
+ \\
++ \\
+ \\
-\end{array}$ & $\begin{array}{r}+ \\
+ \\
- \\
-\end{array}$ & \\
\hline \multirow{2}{*}{ Samples } & \multicolumn{5}{|c|}{ Components number } \\
\hline & 2 & 10 & & & \\
\hline $\begin{array}{l}\text { n6A t6B } \\
\text { n6A t6D } \\
\text { n6B t6A } \\
\text { n6B t6D } \\
\text { n6D t6A } \\
\text { n6D t6B } \\
\text { dt } 6 \mathrm{~B}-\mathrm{S}\end{array}$ & $\begin{array}{r}+t \\
+ \\
- \\
+ \\
+\frac{1}{+}\end{array}$ & $\begin{array}{r}++ \\
+ \\
- \\
+ \\
+ \\
+ \\
+\end{array}$ & & & \\
\hline
\end{tabular}

\begin{tabular}{lllllll}
\hline & \multicolumn{8}{l}{ Components number } \\
\cline { 2 - 7 } & 2 & 3 & 4 & 8 & 9 & 11 \\
\hline
\end{tabular}

n7A t7B

n 7 A t7D

n7B t7 A

n 7 B t7 D

n 7 D t $7 \mathrm{~A}$

n 7 D t7B

de $7 \mathrm{~A}-\mathrm{L}$

dt $7 \mathrm{~A}-\mathrm{S}$

dt $7 \mathrm{~B}-\mathrm{L}$

dt $7 \mathrm{~B}-\mathrm{S}$

dt $7 \mathrm{D}-\mathrm{S}$

$\begin{array}{rrrrrr}+ & + & + & ++ & + & + \\ + & ++ & ++ & + & + & + \\ + & + & + & - & - & + \\ + & +t & + & - & - & + \\ + & - & - & + & + & + \\ + & - & - & ++ & +t & - \\ + & + & + & + & + & + \\ + & + & + & + & + & + \\ + & + & + & + & + & + \\ + & + & + & + & + & + \\ + & + & + & + & + & +\end{array}$

* n-nulli; t-tetra; dt-ditelosomic

** + as in the euploid; - absent; ++ enhancement; components not listerl, as in the euploid

Ae. squarrosa maps do show such spots (RodriguezLoperena et al., submitted).

\section{Discussion}

It can be concluded from these results that the gene (s) for component 5 are located in chromosome $\operatorname{arm} 3 \mathrm{D} \beta$ and those for components $6,7,14$ and 15 in $3 \mathrm{BS}$. Working with the same extract, Waines 


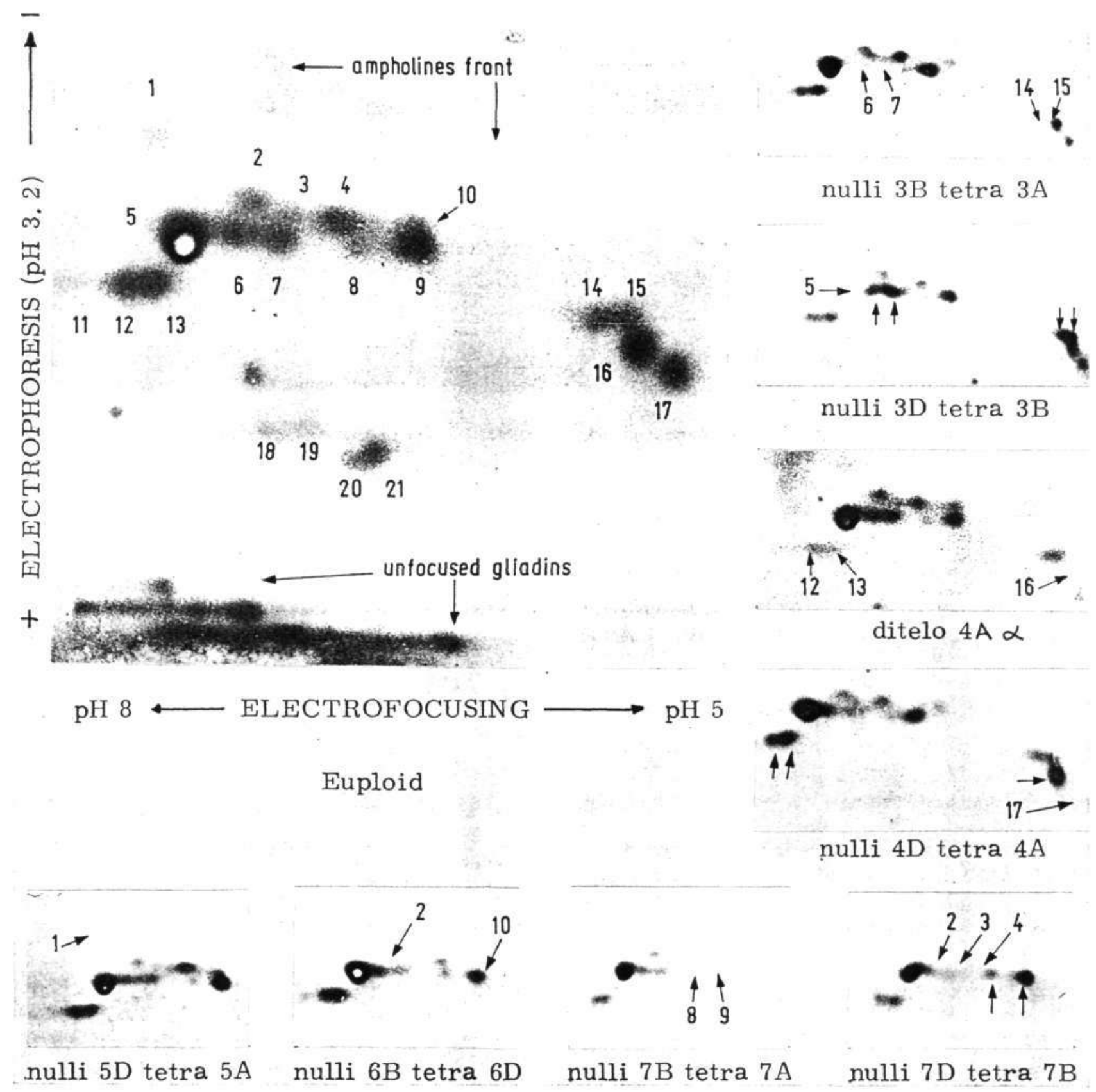

Fig. 1. Protein maps obtained by combined electrofocusing and electrophoresis of non-gliadin proteins of the $70 \%$ ethanol extracts of the euploid, a ditelosomic and 7 nullitetrasomics of Triticum aestivum cv. Chinese Spring. Only the section of the map affected in each aneuploid is shown. Missing spots are indicated by their map number and an arrow. Unnumbered arrows indicate enhancement of the spots pointed to

(1973) found that chromosome 3D modified the intensity of a complex band which presumably included two proteins found in Aegilops squarrosa. Equally tentative was his assignment of a third Ae. squarrosa component probably present in the D genome of Chinese Spring. He also positively located gene(s) for one electrophoretic band in chromosome 3B. We have demonstrated that components 5, 6, 7, 14 and 15 are also extracted by water (Rodriguez-
Loperena et al., submitted). Noda and Tsunewaki (1972) assigned two components of the buffer soluble proteins to chromosome arms $3 \mathrm{D} \beta$ and $3 \mathrm{BS}$ respectively, using electrofocusing, and Bozzini et al. (1971) have located gene (s) for an albumin, designated PCS, in chromosome $3 \mathrm{D}$ by immunochemical methods. Taking into account isoelectric point, electrophoretic mobility and solubility, it seems likely that component 5 is identical with that assigned by Noda and 
T'sunewaki (1972) to the same chromosonte arm and also with one of the faster moving $A$ e. squarrosa components considered by Waines (1973). However, it seems different from $\mathrm{PCS}$ albumin because the isoelectric point of the latter (pH 9.1) is outside the $\mathrm{pH}$ range $(5-8)$ of the amplolines used in our maps and would not be detected on extraction witl $70^{\circ}$ \% ethanol. Components 6 and 7 of our map probably correspond to band 4 of Noda and Tsunewaki (1973) and components 14 and 15 to band 3 .

Data for homoeologous group 4 are consistent with the location of genes for components 12,13 and 16 in chromosome arm $4 A \beta$ and for component 17 in chromosome 4D. Components 12 and 13 are included in band $\mathrm{CM}_{3}$ of the chloroform-methanol extract, which was assigned to chromosome 4A by Aragoncillo (1973), and in all probability, in the band at $83 \mathrm{~mm}$ of Waines (1973), which he found to be enhanced in the tetra 4A's. Similarly, component 16 would be part of the band at $69 \mathrm{~mm}$ and component 17 of the one at $65 \mathrm{~mm}$. We have not seen any effect of cliromosome $4 \mathrm{~B}$. Since component 17 is hardly extracted with water and has a different isoleectric point from the Jib 0,19 albumin of Bozzini at al. (1971), which was assigned to $4 \mathrm{D}$, their being identical is excluded.

Component 1 can be assigned to chromosome 5D, although it is not enlanced in nulli $5 \mathrm{~A}$ tetra $5 \mathrm{D}$, and component 10 to $6 \mathrm{~B}$. We are not aware of any report about proteins of their electrophoretic mobilities controlled by these cluromosomes.

in especial case is that of component 2 , which is not synthesized by nulli $6 \mathrm{~B}$ tetra $6 \mathrm{~A}$, nulli $6 \mathrm{~B}$ tetra $6 \mathrm{D}$ and nulli $7 \mathrm{D}$ tetra $7 \mathrm{~B}$, but is present in nulli $7 \mathrm{D}$ tetra $7 \mathrm{~A}$ and in nulli $7 \mathrm{~A}$ tetra $7 \mathrm{~B}$. Obviously the structural gene(s) for component 2 have to be located in chromosome $6 \mathrm{~B}$. The absence of this component in nulli $7 \mathrm{D}$ tetra $7 \mathrm{~B}$ has to be ascribed to the inhibitory effect of four doses of chromosome $7 \mathrm{~B}$, which is not effective in the presence of $7 \mathrm{D}$. Similar phenomena have been observed by Shepherd (1968) in the gliadins and by Orth and Bushuk (1974) in the glutenins.

Components 3 and 4 are controlled by chromosome arm 7DS and components 8 and 9 by 7 BS. GarcíaOlmedo and Carbonero (1970) located genes for two components of the chloroform-methanol extract, designated $\mathrm{CM} 1$ and $\mathrm{CM} 2$, in chromosomes $7 \mathrm{D}$ and $7 \mathrm{~B}$ respectively. Rodriguez-Loperena et al. (submitted) have demonstrated that $\mathrm{CM}_{1}$ includes components 3 and 4 and CM2 is composed of 8 and 9. Furthermore, CH1 is identical with the band at $105 \mathrm{~mm}$ of Waines (1973) and CM2 is included in a very wide band of his pattern, between 90 and $100 \mathrm{~mm}$, which may explain why he did not detect any effect of $7 \mathrm{~B}$ in that zone.

Component 11 is a faintly stained spot that seems to be associated with chromosome $7 \mathrm{D}$ and is included in band $\mathrm{CM} 3$ of the chloroform-methanol extract (Rodriguez-Loperena et al., submitted).
Components 18, 19, 20 and 21 luave not been assigned to any cloromosome, probably because genes coding for them are located in more than one pair of homoeologous chromosomes. The fact that component 21 is affected by cliromosome $1 \mathrm{~A}$ suggests that group 1 might be involved.

These data about the chromosomal control of nongliadin proteins extracted with $70 \%$ ethanol are essentially consistent with the genome assigument based on the protein maps of tetraploid and hexaploid wheats and of Aegilops squarrosa (Rodriguez-Loperena, submitted).

Because of their low intragenomic variability (Johnson, 1972; Aragoncillo, 1973; Rodriguez-Loperena et al., submitted), the components of this group of proteins should be, at the present degree of resolution, excellent chromosome markers in phylogenetic studies.

\section{Acknowledgements}

Wo wish to acknowledge the gift of samples ly Drs. E. R. Sears, T. Mello-Sampayo and J. IR. Lacadicna and the technical assistance of $\mathrm{J}$. $\mathrm{A}$. Munuera. This studly wats supported by a grant of the Junta de Jenergia Niuclear, Madricl, Spain.

\section{Literature}

Aragoncillo, C.: Proteinas CM en Triticum spp. P'nrificación, caracterización y regulación genética. J). Ing. Agr. Thesis. Polytechnical University of Madrid (1973).

Boyd, W. J. R., I.ee, J. W: The control of wheat gluten synthesis at the genome and chromosome levels. Experientia $23,332-333$ (1967).

Joyd, W. J. R., Lee, J. W., Wrigley, C. W. : The D-genomo and the control of wheat gluten synthesis. Hixperientia 25. $317-319$ (1969).

Bozzini, A., Cantagalli, P., Piazzi, S. E.: Chromosomal location of the genetic control of two proteins specific. ally attributed to hexaploid wheat by imnunochemical methods. Eur. Wheat Aneuploid Newslett. 3, 16-17 (197t).

Eastin, J. D., Morris, R., Schmiclt, J. W., Mattern, 1', J., Johnson, V. A.: Chromosomal association with friactin proteins in the wheat varicty "Cheyenne". Cr(1) Sici. 7, 674-675 (1967).

Garcia-Olmedo, F., Carbonero, 1': Hontoedoyous protein synthesis controlled by homoeologous chromosomes in wheat. Phytochemistry 9, 1495-1497(1970).

García-Olmedo, $F_{\text {., }}$ Carbonero, $P_{\text {., Aragoncillo, }}$., liernandez de Caleya, $\mathbf{R}$., Torres, V.: Expression of homocologous molecular systems in wheat alloploids. I'roc. VIIth Congress of EUCARPIA Budapest (in press 1974).

Hall, O., Johnson, B. L., Olered, R.: Evaluation of genome relationships in wheat from their protein homulengies. l'roc. 2nd Int. Wheat Genetics Symp., lund 1963. Hereditas, Supp. Vol. 2, 47-54 (1966).

Jha, M. P., Kaul, A. K., lkaghaviah, 1'., Swaminathan, M. S.: Identification of chromosomes carrying factors for seed storage proteins. Wheat Inform. Surv. No. 32, $9-13(1971)$.

Johnson, B. L.: P'rotein electrophoretic profiles and the origin of the $B$ genome of whent. Proc. Nat. Acad. Sci. USA 69. 1398-1402 (1972).

Johnson, 13. L., Hall, O.: Analysis of phylogenetic affinities in the Triticinae by protein eketroploresis. Amer. J. J3ot. 52, 506-513(1965). 
Morris, 1R., Schmidt, J. W., Blattern, I'. J., Johnson, V. A.: Chromosomal locations of genes for ligh protein in the wheat cultivar Atlas 66. J'roc. 4h $^{\text {th }}$ Int. Wheat Genct. Symp. Columbia, eds. Sears, L. R., Sears, I.M.S. (University of Missouri) pp. 715-718 (1973).

Noda, K., Tsunewaki, K.: Analysis of seed proteins in ditelosomes of common wheat. Japan. J Gienct. 47, 315-31S (1972).

Orth, R. A., Bushuk, W.: Studies of glutenin. Vil. Chromosomal location of genes coding for subusits of glutenin of common wheat. Cercal Chem. 51, 158-126 (1974).

Riley, R., Ewart J. A. D.: The effect of individual ryechromosomes on the aminoacirl content of wheat grains. Genet. Res. Camb. 15, 209-219 (1970).

Rodriguez-Loperena, M.A., Aragoncillo, C., Carbonero, I', García-Olmedo, F.: Heterogeneity of wheat endosperm proteolipids (CM proteins). Submitted for publication (1974).

Sears, E. R.: The aneuploids of common wheat. Mo. Agr. Exp. Sta. Res. Bull. 572, 58 pp. (1954).

Sears, E. R.: Chromosome mapping with the aid of telocentrics. Proc. 2nd. Int. Wheat Genet. Symp., Jund 1963. Hereditas, Supp. Vol. 2, 370-381 (1966).

Shepherd, K. W. : Chromosomal control of endosperm proteins in wheat and rye, l'roc, 3rd. Int. Wheat (ienet. Symu, (Aust. Acad. Sci., Canlerra) pp. $\$ 6-96$ (1968).

Siddigui, I. A.: I'rotein content and quality of wheat chromosome sulostitutiou lines. Hereditas $71,157-160$ (1972).

Solari, R., Favret, E. A.: I.inkalge of genes regulating the protein constitution of wheat endosperm. Wheat Newsletter 14, 10-21) (1967).

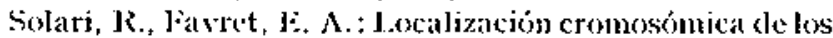
genes responsibles de la síntesis de proteinas det endosperme de trigo. 13ol. Cenet. Inst. Fitotec. Castelar 7 , $23-26(1970)$.

Waines, J. G.: Electrophoretic-systematic studies in Aegilops. Ph. D. Thesis. Univ. Callif. Kiverside. Jiss. Absts. No. 60-19:131 (1969).

Waines, J. G. : Chromosomal location of gencs controlling endosperm protein production in Triticum aestivum cv. Chinese Spring. 1'roc: $4^{\text {th }}$ Int. Wheat Genet. Symp. Columbia, eqls. Sears, JE.IR, and Sears, I..M.S. (University of Missouri) pp. $873-877$ (1973).

Wrigley, C. $W_{\text {. }}$ Protein mapping by combined gel electrofocusing and electrophoresis: Application to the study of genotypic variations in wheat gliadins. Biochem. Genet. 4, 509-516(1970).

Wrigley, C. W., Shepherd, K. W.: Jectrofocusing of grain proteins from whest genotypes. Ann. N.Y. Acad. Sci. $209,154-162(1973)$. 